\title{
A Dominant Global Translation Strategy in Thai Translated Novels: The Translations of Religious Markers in Dan Brown's Thriller Novels
}

\author{
Wiriya Inphen (วิริยะ อินทร์เพ็ญ) \\ Doctoral Student, Faculty of Humanities and Social Sciences, \\ University of Jyväskylä, Jyväskylä, Finland \\ inphenwiriya@hotmail.com
}

\begin{abstract}
When translation is considered as an integral part of larger social systems (Even-Zohar 1990), the ways in which translations are produced to serve readers' specificity could be affected. This paper examines whether there is a preference for a specific global translation strategy due to a readership that is specialized in terms of education level. Adopting Venuti's (1995/2008) division of global translation strategies into exoticizing and domesticating translation, it examines the frequency of local translation strategies, which are part of a global translation strategy, used in translating English-Thai religious markers in Dan Brown's Angels and Demons, The Da Vinci Code, The Lost Symbol, Inferno and Origin. The religious markers cover words/phrases of belief systems in either Eastern or Western culture. The results show that exoticizing translation is a dominant global translation strategy that translation agents, such as translators and editors, use in literary translations of Anglo-American novels.
\end{abstract}

\section{Keywords}

translated Anglo-American popular fiction - Thai literary translation - global translation strategy - local translation strategy - religious markers - specialized readership 
บทคัดย่อ

กลวิธีเด่นของการแปลแบบองค์รวมในนวนิยายแปลของไทย: การแปลตัวบ่งชี้ทางศาสนา ในนวนิยายเขย่าขวัญของแดน บราวน์

การแปลเป็นส่วนหนึ่งของระบบต่างๆ ในสังคม (Even-Zohar 1990) ดังนั้น การที่ผู้อ่านมี คุณลักษณะเฉพาะเจาะจงย่อมส่งผลต่องานแปล ในงานวิจัยนี้ ผู้วิจัยต้องการศึกษากลวิธีที่เป็นที่นิยม ของการแปลแบบองค์รวม (global translation strategy) ในการแปลวรรณกรรมที่มุ่งสนองผู้อ่าน ที่มีการศึกษา การวิจัยได้ใช้แนวคิดการแปลแบบองค์รวมของ Venuti $(1995 / 2008)$ ที่แบ่งการแปล เป็นสองประเภทคือ การแปลโดยคงความเป็นต่างประเทศ (exoticizing translation) และการ แปลตามภาษาเป้าหมาย (domesticating translation) เป็นแนวคิดเพื่อนับความถี่ของกลวิธีการ แปลในระดับเฉพาะ (local translation strategy) ที่ใช้ในการแปลตัวบ่งชี้ทางศาสนาในภาษา อังกฤษและไทยของนวนิยายเรื่องเทวากับซาตาน (Angels and Demons) รหัสลับดาวินชี (The Da Vinci Code) สาส์นลับที่สาบสูญ (The Lost Symbol) สู่นรกภูมิ (Inferno) และออริจิน (Origin) ของแดน บราวน์ (Dan Brown) ตัวบ่งชี้ทางศาสนาหมายถึงคำหรือวลีที่เกี่ยวกับศาสนา และ/หรือระบบความเชื่อในวัฒนธรรมตะวันตกและตะวันออก เมื่อพิจารณาเรื่องคุณลักษณะ เฉพาะของผู้อ่านชาวไทยแล้ว ผลวิจัยแสดงให้เห็นว่าบุคคลที่เกี่ยวข้องกับการแปล ไม่ว่าจะเป็นผู้ แปลหรือบรรณาธิการ ต่างนิยมใช้การแปลแบบต่างประเทศเป็นหลักในการแปลวรรณกรรม อังกฤษอเมริกัน

\section{Introduction}

The Thai readership has been claimed to be specialized in terms of educational background (Ratchatasuwan 2017). This specificity is rather important for translations that are produced and sold in the Thai literary market. In this socially stratified and unique environment, the ways in which translation strategies are adopted in Thai translated novels are seen to have been affected by the readers' specificity, given the fact that translation is part of larger social systems, showcasing Even-Zohar's (1990) polysystem theory. With the aim to serve the needs of target readers, translation agents, such as translators, editors, and publishers, have adhered to translation strategies that would not only solve translation problems but meet the expectations of their readers (cf. Lefevere 1992).

Based on the specific Thai readership context, this article aims to find out whether the Thai translation of Dan Brown's five translated novels in his thriller series: Angels and Demons (Brown 2000), The Da Vinci Code (Brown 2003), The Lost Symbol (Brown 2009), Inferno (Brown 2013) and Origin (Brown 2017), manifests a preference for a specific global translation strategy that is used by 
translation agents, such as translators and editor(s), involved in translation processes or not.

The material of this study consists of religious markers from Dan Brown's five bestselling thriller novels as stated above and their translations: “เทวากับซาตาน" (back translation - Deva and Satan), translated by Oradee Suwankomol and Anurak Nakarin (Brown 2004a), "รหัสลับดาวินชี" (back translation - The Secret Code of Da Vinci) by Oradee Suwankomol (Brown 2004b), “สาส์นลับที่สาบสูญ” (back translation - The Lost Message) by Oradee Suwankomol (Brown 2010), "สู่นรกภูมิ" (back translation - To the Hell) by Oradee Suwankomol (Brown 2014), and "ออริจิน" (back translation - Origin) by Anurak Nakarin (Brown 2018).

Specifically, I will study the religious markers of the original English versions and their translations into Thai. The religious markers are chosen because Dan Brown's novels mainly involve Anglo-American religious markers that are central to the plot. In this study, the religious markers are defined as covering any elements related to religions and/or belief systems of any Western and/or Eastern cultures. In order to delimit the scope of the material, given the fact that venues and items used in the novels are central to their plots, the religious markers related to venues and items are chosen as materials in this study.

The analysis of this study is quantitative. Because the ultimate aim is to find out a dominant global translation strategy in the translations of these five translated novels, occurrence sums of local translation strategies are counted. The sum of local translation strategies is expected to demonstrate a preferred global translation strategy - whether it is an exoticizing or a domesticating translation.

This article is divided into the following sections: aim and hypothesis, theoretical background, material and methods, results, and conclusions. Firstly, the aim and hypothesis section primarily gives related Thai literary background that leads to the study's aim to find a dominant global translation strategy in the translations. With this aim, the hypothesis is formed based on the readership's specificity and it argues that the Thai specific context could affect the ways in which local translation strategies are chosen as part of a global translation strategy. Secondly, in the theoretical background section, the concepts of local and global translation strategies are elaborated to give a framework to the analysis and discussion. Thirdly, the material and methods section delves into the importance of religious markers that are used as material and how the local translation strategies are categorized to reflect a global translation strategy. Fourthly, the results section shows that the study's question has been answered: exoticizing translation is dominant as a global translation strategy in the translations. Lastly, the conclusions section restates that finding and points to the limitations of the study. 
As Thai literary background is an important context of translated literature in Thailand, it is necessary to elaborate it in detail before continuing to explore the aim and hypothesis of this study.

A transition from Thai traditional to modern literature has, to most extent, formed an elite readership that was literate. From the perspective of literary history, readership was affected by both the arrival of Western translated fiction and the country's modernization period. Firstly, Thai literary interest strongly shifted from verse to prose literature when the first English novel "Vendetta" (1886) by Marie Corelli or ความพยาบาท 'The Vengeance' was translated into Thai by Mae Won (a pseudonym of Phraya ${ }^{1}$ Surintracha, a high-ranking public servant) in 1902 (Chittiphalangsri 2014, 3). The translated novel came to Thailand during the period when the country was in urgent need of modernizing. ${ }^{2}$ This event not only influenced literary interest in the Western prose genre but also, in some respects, helped to confine literature to a specific group of readers. At that time, the case of a specific readership was evident as there was a literary circle formed by King Rama VI (reigned 1910-1925). King Rama VI, the first Western-educated Thai king, studied at Oxford University in the UK and exerted great influence on the Siamese ${ }^{3}$ literary circle and society. In his reign, the King favored enthusiastic artists and frequently rewarded them with valuable items, money, and even government positions and titles (Rutnin 1988, 28). This affected Siamese society in the long run because it, in some way, gives evidence that literature was tied to those literate citizens who, during that period, were Western-educated elites.

Later, Thai readership in the modern Thai literary market remains specific. Even though the Thai readership has extended from the elites to readers of all walks of life at the present time, the readership is not seen generic but rather specific. To clarify, Thais do not seem to favor reading. Based on statistical figures on reading interest compiled by the National Statistics Office, ${ }^{4}$ the

1 "Phraya" was an administrative rank in the Siamese government equivalent to the position of director-general in the current Thai governmental system.

2 The modernization period took place during the reign of King Rama v (1868-1910). According to Mattani Mojdara Rutnin $(1988,6)$, modernization was a measure "to use Western knowledge to fight against and to fend off the West". In order to gain Western knowledge, King Rama v sent his children, cousins, and people from noble families to study in Europe and the US in order for them to return to work in the government and develop the country towards Western models (Rutnin 1988, 13).

3 Thailand was named Siam until 1949.

4 By National Statistics Bureau of Thailand, Ministry of Information and Communication Technology. January, 62015 <http://service.nso.go.th/nso/nso_center/project/table/files/ S-reading/2556/00o/oo_S-reading_2556_0oo_0200oo_01900.xls $>$. 
majority of readers who read for pleasure are between the ages of 15 to 24 only. Significantly, these statistics reflect readership situations that currently appear in the Thai literary market, especially the market of translated literature. In an interview, the editor of Praew Translation Publisher ${ }^{5}$ (Chiwasujin 2016) believes that the Thai readership is, to a large extent, specific. Firstly, Praew Translation Publisher diversifies its sub-publishers in order to best accommodate different translated fiction genres: Praew Translation for thrillers, Rose Publisher for romances, and Spell Publisher for speculative fiction. In addition, these sub-publishers target different readers. For example, Praew Translation and Rose Publisher target readers of working age, and Spell Publisher targets young adults. Secondly, distribution channels suggest that their target market is not generic. In normal practice, these translated novels are distributed to the publisher's bookstores (i.e. Nai-In) and its affiliated bookstores in the city, such as Se-Ed, Kinokuniya, and Asia Books (online channels included). Interestingly, the sales channels do not include either street book kiosks or book kiosks at convenience stores, such as $7 / 11$ which are widely available throughout the country. Lastly, book prices can be seen as one of the factors that determine the readers as well. According to National Income at Current Market Prices by Type of Income: 1990-2013 Report, ${ }^{6}$ the average annual income of the country per person was 131,579 Thai Baht $\left(3,366.10\right.$ Euros $\left.^{7}\right)$. When minimum daily wages (approx. 300 Thai Baht or 7.7 Euros) and the price of a translated novel (e.g. 2015's Angels and Demons (425 Thai Baht (10.90 Euros)) are compared, translated novels can be expensive for the majority.

Based on this specificity of the local readership, the ways in which translated novels are manipulated by translation agents are not only interesting but unique to the Thai literary context.

In a publishing house, Praew Translation Publisher in this study, translation agents, specifically the editors and chief editors, have significant roles in manipulating translations. Based on an interview with the editor (Chiwasujin 2016) at Praew Translation Publisher, editors, to a large extent, have greater

5 Amarin Printing and Publishing Public Company Limited is a parent company of Praew Translation Publisher that publishes all Dan Brown's translated novels. The parent company shares a rather large market in the Thai literary market as it runs at least 16 sub-publishers which cover a wide range of literature (fiction, translated fiction, children literature, comics, magazine, et cetera).

6 By National Statistical Office of Thailand, Ministry of Information and Communication Technology. January, 62015 <http://service.nso.go.th/nso/web/statseries/statseries15.html>.

$7 \quad 39.09$ Thai Bath is equal to 1 Euro according to the average selling rate of Bank of Thailand as of 10.03.2016. This exchange rate is applied for other currency conversions throughout the paper. 
authority than translators. That is, editors usually have sole authority to review, edit and accept translated works while having limited consultations or even prior permission to change translated works submitted by the translators. In the interview, Dan Brown's editor (Ratchatasuwan 2017) also noted that Thai readers of translated literatures usually have at least a high school education and are able to tolerate foreignness retained in the translations. For example, this editor believes that "people who are less educated are likely not to buy translated books (my translation)". In addition, the same editor further commented that - (In normal translation processes), "proper names, e.g. venue names, subject names, et cetera, are transliterated/ translated literally into Thai." ( $m y$ translation). On this basis, it is possible that the translation agents encourage their translators to retain or even accept foreign items in translation.

Thus, with this specificity in mind, the article wants to determine whether the translations of Dan Brown's translated novels demonstrate any preference for a specific global translation strategy employed by translation agents involved in translation processes of Anglo-American popular fiction in Thailand.

Readership is important for a study of translation. Based on Tarek Shamma's (2009) study, the translation from Arabic into English of The Arabian Nights points out that target readership plays a significant role in translation productions. Given the fact that the target audience of the novel's English version has been pre-determined (Shamma 2009, 15), the translator therefore deliberately employed exoticizing translation with the aim to create an air of exoticism (seen as a foreignizing effect) that was preferred by culturally literate readers (Shamma 2009, 15, 65, 80). Similarly, considering the specialized Thai readership, contemporary Thai readers are mostly young, fairly well-off and at least in the view of the publishing industry, educated. On this basis, it is assumed that there is a link between the specialized readership and the ways in which translators choose local translation strategies to translate novels from dominant Anglo-American countries.

For this reason, the hypothesis of this study is that there is a preferred global translation strategy that translation agents adopt in literary translations of Anglo-American novels.

\section{Theoretical Background}

Translators decide to adopt different translation strategies for various reasons, such as to serve their target-culture readers. Translators' decisions, for example, include choices in local translation strategies that are meant to solve translation problems arising at a micro level, e.g. translation problems of linguistic 
non-equivalences between source and target languages, translation problems of cultural non-existence in a target language, et cetera. On the other hand, translators' decisions also occur at a higher level - a macro level. At this level, their decisions include global translation strategies that deal with the whole text in a translation. In this sense, global translation strategies can be viewed as a translation profile on which translators decide to translate a particular text type or genre. Therefore, as discussed earlier, local translation strategies can be viewed as part of global ones. The relationship between local translation strategy and global translation strategy is evident in Andrew Chesterman's (2000) work. Chesterman states that, in a translation work, global translation strategy and local translation strategy are relative in that the former is considered at a more general level while the local translation strategy is chosen at a more specific (local) level (Chesterman 2000, 90). To be more specific, global translation strategies are ways translators consider to translate text types or genres (Chesterman 2000, 90), and local translation strategies are methods translators apply to solve specific translation problems arising from differences between the texts: how to translate the text, items, et cetera (Chesterman 2000, 90-91). In a translation, global translation strategies are thus a reflection of what translators adopt at a macro level.

Local translation strategies have been extensively studied and there have been attempts to classify them into two opposite poles: source-text oriented and target-text oriented translation. Despite extensive studies in the past, the ways in which translators adopt these translation strategies in their translations remain an interesting field to explore. This idea of two binary poles was first mentioned by Friedrich Schleiermacher (1838/1977) who states that translators either move the readers close to the source text or, in the opposite way, move the source texts closer to the readers. The former strategy aims to retain foreign words/items that can be unfamiliar to the readers, e.g. "Illuminati" transliterated into Thai as "อิลลูมินาติ" (back translation - Illuminati), while the latter introduces translated words/items that are familiar in the target culture, e.g. "the basilica" translated into Thai as "มหาวิหาร" (back translation - the great vihara). More recently, Lawrence Venuti (1995/2008) is among a number of prominent scholars who have brought this idea back into the field. Venuti (1995/2008) bases his studies in the Anglo-American literary context and links his idea of foreignizing translation to source-text oriented translation, and domesticating translation to target-text oriented translation.

Based on Venuti's (1995/2008) studies, adoptions of foreignizing and domesticating translation in translations are different in cultures other than the Anglo-American. Venuti $(1995 / 2008,1)$ argues that fluency in the form of domestication is preferred by literary readers and accepted by reviewers and 
critics in Anglo-American society. Domesticating translation, in Outi Paloposki's $(2011,40)$ sense, refers to adaptations of foreign cultural words/items to fit the target culture. On the other hand, foreignizing translation refers to the ways translators preserve cultural foreignness such as venues, proper names, et cetera (Paloposki 2011, 40). In Venuti's (1995/2008, 15-16) terms, foreignizing translation not only aims to demonstrate foreign cultural differences that do not conform to cultural conventions of the target culture, but stresses minoritizing cultural differences (Venuti 1995/2008, 20). This translation strategy, which, for example, advocates the adoption of foreign items that challenge current literary standards to signal foreignness, is thus encouraged as a form of dominant-cultural resistance (Venuti 1995/2008, 16). In addition to the foreignizing strategy, Venuti $(1995 / 2008,160)$ also explicitly points out that foreignizing translation differs from exoticizing translation (Venuti 1995/2008). Exoticizing translation includes, for example, translations that retain sourcetext venue names, names of persons/subjects, and other unfamiliar source-text words/ phrases. However, in contrast to foreignizing translation, exoticizing translation is adopted with the aim to give foreignizing effects that indicate the exoticism of cultural differences that are related to some specific elements of foreign cultures.

The concept related to the ways in which translators retain foreign items in translations has been tested in different cultures (Paloposki 2011), and it points out that the ways in which global translation strategies are used depend greatly on the target-culture context (see also Shamma 2009). For example, in the context where a work of Arabic literature - The Arabian Nights by Edward Burton, was translated for a specialized English readership, Shamma (2009), through examinations of translation strategies and translators' decisions in the Arabian context, found that the translator retained foreign items in the translation to serve the needs of foreignizing effects (that give a sense of exoticism) that were preferred by the readers who wanted to explore differences of foreign cultures. In this view, the strategies used did not aim to stress cultural differences but to exoticize the texts. This infers that exoticizing translation was deliberately used as a translation strategy to gain acceptance from the target audience. This strategy, such as e.g. borrowing Arabic words in the English translation, was deliberately employed to create exoticism that was preferred by the target readers, and this helped Burton to "gain acceptance and circulation for his translation" (Shamma 2009, 65, 80). In addition, exoticizing translation is related to elitism as the exoticizing of The Arabian Nights was aimed at and accepted by the audience who was assumed to be culturally literate and rather wealthy. The audience was pre-determined because the translation was published by a relatively costly subscription (Shamma 2009, 15). In supporting 
Shamma's study, Kjetil Myskja (2013) reviews Venutian foreignization's applicability and states that differences between foreignizing and exoticizing translation are also hard to frame and far from having a clear-cut boundary. In tracing Shamma's and Venuti's responses, Myskja further states that Venuti (1995/2008) accepts that diverse readerships are critical contexts that have manipulative effects on translation productions (Myskja 2013, 15, 17).

The ways in which local translation strategies are used in literary translations have been studied in Thailand. However, these studies have been limited to adoptions of local translation strategies to solve translation problems at the textual level without having links to target readers. In his study, Mett Robrue (2007) identifies translation strategies used in solving translation problems in The Da Vinci Code and concludes that the translator used transliteration, literal translation, and literal translation with explanations (in the forms of footnotes or parentheses) to translate words/ phrases that are specific to Western culture. Interestingly, the study did not further explain why such translation strategies were adopted. Following this gap, the relationship between the ways in which local translation strategies are adopted in literary translations and the readership in Thailand is seen as significant.

In sum, as discussed above, given the fact that the Thai readership is seen specialized in terms of education level, the acceptance of foreignness in translation is presumably linked to the specialized readership to evoke a foreign atmosphere in the translations. As a result, Venuti's $(1995 / 2008,160)$ exoticizing translation strategy is central to the study. Thus, this framework will be used to identify local translation strategies, whether they are domesticating or exoticizing translation strategy, that the translation agents used in the translations of Dan Brown's five novels. Details of local translation strategy categorizations are elaborated in the Material and Methods section. As for the findings, a global translation strategy that is dominant in the translations will be discussed to indicate its applicability and to identify any links to the readership in the Thai literary market.

\section{4}

\section{Material and Methods}

The material of this study consists of the English-Thai translations of religious markers in Dan Brown's five bestselling novels: Angels and Demons (Brown 2000), The Da Vinci Code (Brown 2003), The Lost Symbol (Brown 2009), Inferno (Brown 2013) and Origin (Brown 2017). Religious markers are defined as any marker related to religions and/or belief systems in either Western or Eastern culture. Given the fact that the novels' plots all play out in the West, religious 
markers represent great differences between the two cultures. These five novels constitute Dan Brown's suspense-thriller series. They feature Robert Langdon, a Harvard professor in symbology, as the protagonist on a mission to solve mysterious riddles (in the forms of ancient symbols hidden in different religious venues, such as St. Peter's Basilica (in Angels and Demons), the tomb of Mary Magdalene (in The Da Vinci Code), the House of the Temple (in The Lost Symbols), the Piazza di Santa Croce (in Inferno), and the monastery of El Escorial (in Origin). These mysterious riddles are not only related to religious venues but include religious items, such as "the Great Seal", "the Cup of Christ", "the Masonic ring", "La Mappa dell' Inferno", and "a Carmelite cross" (in Angels and Demons, The Da Vinci Code, The Lost Symbols, Inferno and Origin, respectively). Following these mysterious riddles, it is rather obvious that religious venues and items figure prominently in the central plot of these novels.

Before continuing to the data collection section, it is important to provide a brief synopsis of the novels. To begin, in Angels and Demons, Robert Langdon is on a mission to decipher a set of religious symbols associated with the Illuminati (a secret social group who, in the story, is opposed to the Catholic church) in order to save the cardinals who have been kidnapped from the conclave. In The Da Vinci Code, Langdon needs to decode hidden messages created by the Priory of Sion (a secret society that includes Leonardo Da Vinci as its secret leader) in order to find the Holy Grail and a message that could affect Christian belief. Next, The Lost Symbol's mysterious symbols directly concern the secrets of the Freemasons (an ancient fraternity) that reveal a truth that enlightens human spirits. Inferno's mysterious puzzles are set by a scientist genius and a Dante fanatic who plans to use a plague to reduce the world's population. Lastly, in Origin, the mystery is hidden in poetry and Langdon needs to solve it in order to access Kirsch's (a scientist) presentation that aims to reveal to the public the origins of human life.

Religious markers used in the analysis are confined to religious markers related to venues and items. Religious venues refer to places that are related to religious activities (e.g. "the Vatican Conclave"), subjects/ groups (e.g. pope, the Priory of Sion), and ideas (e.g. the Power of Creation), while religious items refer to objects related to or used in conjunction with the mentioned activities, subjects/groups and ideas.

For the analysis, religious markers related to venues and items are collected from the chapters that account for 50 (fifty) percent of each novel. In total, the five novels produce 984 religious markers.

As the analysis aims to identify a dominant global translation strategy, the occurrence sum of local translation strategies adopted in the translation is important. This means religious markers are collected in order to build source-text 
and target-text corpora, whose aim is to determine the frequencies of local translation strategies. Therefore, a quantitative analysis alone is seen as sufficient and applicable (see also Saldanha and O'Brien 2014, 22-23).

In order to identify local translation strategies used in the five translated novels, previous studies related to the translation of culture-specific items are considered. As religious markers adopted in the novels are specific to Western culture, e.g. religious venues and items related to Catholicism, these items generally exist in the West but not in Thai culture. Looking at culture-specific items, Javier Franco Aixelá $(1996,57)$ states that culture-specific items can pose challenges in a translation because there are rarely equivalences of the source-text item in the target texts (see also Davies 2003, 69; Liang 2016, 42). Similarly, Ritva Leppihalme's (2001) study of translations of realia, also, reflects the same idea. In her study, realia refer to words or phrases that represent real things in the world that cannot be fully explained by linguistic features only (Leppihalme 2001, 139), and, as a result, realia can pose translation challenges. In this view, religious markers in this study conform to the idea of culture-specific items due to non-equivalence between the Anglo-American and Thai culture.

The categorization of local translation strategies in this study is adapted from previous studies' existing categorization of local translation strategies. The categorization in previous studies is valid for the current study because all are text-based categorizations. That is, the categorization arises from a comparison of texts between two different languages: culture-specific items in literary translation (English into Spanish, Aixelá 1996; English into French, Davies 2003; English into Chinese, Liang 2016), translations of realia in students' reports (English into Finnish, Leppihalme 2001). Similarly, the current study explores the translations from English into Thai of Dan Brown's translated novels and as a result the identification of local translation strategies are comparisons between English and Thai. However, categories have been modified slightly due to fundamental differences between English and Thai, both with regard to script and grammar. For example, literal translation is adapted to cover syntactic shifts required as a result of English-Thai structure (e.g. in Thai, a noun precedes an adjective), e.g. "gold cross" as "กางเขนทอง" (back translation - "cross gold"), "Jewish stars" as "ดวงดาราแห่งยิว" (back translation - "stars of the Jew"). The previous studies' categories of the translation of culture-specific items are as follows: Aixelá's (1996, 61-64) deletion, naturalization, limited universalization, linguistic (non-cultural) adaptation, intratextual gloss, extratextual gloss and orthographic adaptation; Davies' (2003, 72-77, 79, 82-83) preservation, addition, omission, globalization and localization; Leppihalme's (2001, 142-144) cultural adaptation, explicitation, omission and addition; and, lastly, Liang's 
(2016, 45-46,48-49) transliteration, rendition, intratextual addition, extratextual addition, naturalization and omission.

Based on the categorization used in the previous studies, there are six adapted local translation strategies: deletion, naturalization, limited localization, in-text gloss, extra-text gloss and literal translation. Details of each adapted strategy are as follows.

\subsection{Adapted Local Translation Strategies \\ 4.1.1 Deletion}

This translation strategy is fairly straightforward as it refers to cases in which source-text elements are removed from the target text. These situations are classified as deletion by Aixelá (1996, 64), omission by Davies (2003, 79), Leppihalme (2001, 144), and Liang $(2016,49)$. For example, "the papal vault" was translated into Thai as 'ห้องเก็บของใต้ดิน' (back translation - vault). The translation shows that while the whole concept of a vault has been kept, the religious concept "papal" has been omitted in Thai.

\subsubsection{Naturalization}

This translation strategy is used in cases where cultural elements specific to the source-text culture are replaced by close equivalences in the target culture. This aims to give more familiarity to the target readers. These circumstances are similar to Aixelá's $(1996,63)$ and Liang's $(2016,49)$ naturalization, Davies' $(2003,83)$ localization, and Leppihalme's $(2001,142)$ cultural adaptation. For example, "chapels" was translated into Thai as "วัดน้อย" (back translation minor temple). The Thai version demonstrates that the word "chapel" was replaced with a more generic term in the target language and in the meantime was modified to fit the target culture. That is, in the Catholic world, "chapel" refers to an attached building that is part of a religious complex, e.g. a cathedral. However, in the translation, the term was replaced with "วัดน้อย" (back translation - minor temple) which gives a Buddhist sense. The word "วัด" (back translation - temple) is a Buddhist place, and the word "น้อย" visualizes the concept of being an attachment to a main venue.

\subsubsection{Limited Localization}

This translation strategy derives from the idea of limited universalization proposed by Aixelá $(1996,63)$ and globalization by Davies' (2003, 82). In adopting this strategy, even though religious markers are replaced with target-text words/phrases that give familiarity to the readers, such translated words/ phrases, still, imply some foreign elements in the translated version. For example, "crucifix" was translated into Thai as "กางเขน" (back translation -a 
cross). In this case, although "crucifix" was replaced with a familiar targetoriented phrase "a cross", the word "cross" remains foreign to most Thais as Thailand is a predominantly Buddhist country.

\subsubsection{Literal Translation}

The idea of literal translation is borrowed from Davies' $(2003,72-77)$ preservation, Liang's $(2016,46)$ rendition, and Aixelás (1996, 61-62) linguistic (non-cultural) adaptation. This strategy is employed in situations where the target-text translation denotes a close reference to the source-text original. As a result, the translated version remains recognizable as being foreign to the target readers. However, given the fact that Thai and English have different linguistic structures, this situation refers not only to cases where religious markers are translated from English into Thai literally by adhering to the lexical and syntactic structure of the source text (e.g. "the bells of St Peter's" to “บรรดาระฆังแห่งมหาวิหารเซนต์ปีเตอร์" (the bells of St. Peter's)), but to translation with lexical and semantic shifts due to the semantic needs of the target text (e.g. "the Masonic ring" to "แหวนเมสัน" (back translation - ring Masonic)). The shift is required as, in Thai, a noun only precedes an adjective. Moreover, literal translation here also extends to cases where source text words or phrases are transliterated into Thai using Thai script (see also Aixelá's (1996, 61) orthographic adaptation and Liang's $(2016,45)$ transliteration). For example, "La Mappa dell' Inferno" was transliterated into Thai as "ลามัปปาเดลลินแฟร์โน” (back translation - La Mappa dell' Inferno).

\subsubsection{In-Text Gloss}

This translation process allows necessary information that would help the readers understand the source-text items to be added as an integral part of the target text. This procedure derives from Aixelás $(1996,62)$ intratextual gloss, Davies' $(2003,77)$ addition, Leppihalme's $(2001,143)$ explicitation, and Liang's $(2016,48)$ intratextual addition. For example, "The Royal Crypt" was translated into Thai as "สุสานหลวงใต้ดิน" (back translation - the underground royal tomb) where the word "ใต้ดิน" (back translation - underground) is added as an integral part of the text to explain "the crypt".

\subsubsection{Extra-Text Gloss}

The notion of this translation strategy is similar to in-text gloss but words or phrases that are added to culture-specific items appear outside the text. This situation is referred to as extratextual gloss in Aixelá's (1996, 62) study, addition in Leppihalme's $(2001,144)$, and extratextual addition in Liang's $(2016,48)$. In this process, explanations can be added as footnotes and/or parentheses in the 
target text to enhance readers' comprehension. For example, "Capella Sistina" was translated into Thai as "คาเปลลาซิสตินา (วัดน้อยซิสตีน)" (back translation Capella Sistina (minor temple Sistine)). The translation includes the transliteration of "Capella Sistina" with the Thai translation of "Sistine Chapel" in parentheses.

In order to determine the occurrence sums of local translation strategies, there is a need to identify whether these adapted local translation strategies are exoticizing or domesticating. Firstly, the classification is based on foreign elements that each local translation strategy retains in the target text. However, in not all cases can one identify a clear boundary between these binary poles. This is because some local translation strategies represent translated elements that can be considered both exoticizing and/or domesticating. As a result, secondly, these translation strategies are necessarily placed on a continuum between the two binary poles in order to indicate degrees to which each local translation strategy inclines towards a certain pole. The classification of these local translation strategies is shown in Table 1 below.

In order to classify the adapted local translation strategies, the idea of foreignizing translation of Outi Paloposki (2011) is borrowed to classify exoticizing translation. Even though exoticizing and foreignizing translation serve different purposes (the former to indicate specific source-text cultural differences while the latter to challenge target-text's literary standard and stress cultural differences (Venuti 1995/2008, 15-16, 20, 160), retentions of foreign items in the translations are a common characteristic of both strategies. According to Paloposki $(2011,40)$, if foreign elements are adapted into or removed from the target-text versions, this can be seen as domestication. On the other end, if foreign elements are retained or preserved in the translated versions, this indicates a foreignizing pole (Paloposki 2011, 40). Based on this concept, deletion can be considered as an absolute domestication as source-text foreign elements are totally omitted from the target text. Naturalization demonstrates a lesser degree of domestication when compared to deletion. This is because source-text elements are not totally deleted but replaced in the target text to

TABLE 1 Local translation strategies on the continuum between the two binary poles 


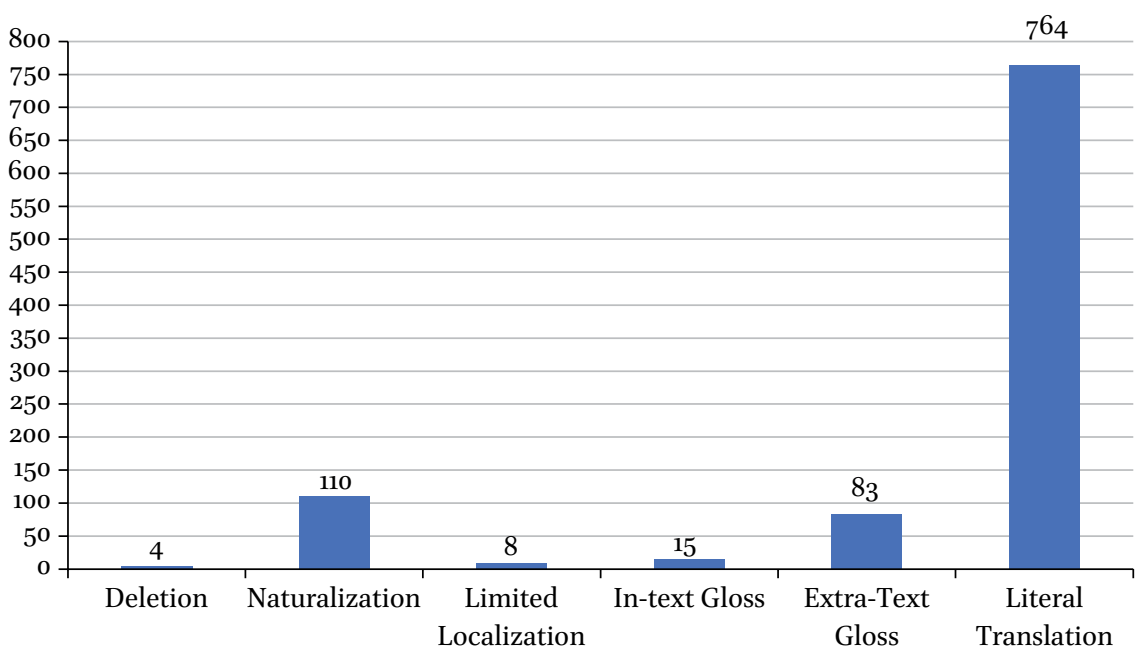

FIGURE 1 The occurrences of local translation strategies

TABLE 2 The local translation strategies and their occurrences on the global translation strategy's binary scale

Deletion (4) $>>$ Naturalization (110) $>>$ Limited Localization (8) $>><<$ In-Text (15)/ Extra-Text Gloss (83) $<$ Literal Translation $(764)$

give a more familiar version to the target readers. Next, as for limited localization, even though foreign elements are replaced with more familiar targetoriented items in the target texts, such replacements, in most cases, denote foreignness in the source culture. The case can be considered as a domesticating translation with a denotation of foreignness and, as a result, demonstrates some degree of exoticization. Therefore, limited localization is placed on the continuum between the two opposite poles.

On the opposite end, literal translation is placed on the exoticizing end of the spectrum because the strategy aims to retain foreignness that is literally translated or transliterated from the source text into the translation. For the other two strategies, in-text and extra-text gloss need to be placed on the scale next to literal translation as both strategies demonstrate a lesser degree of exoticization. That is, although in-text and extra-text gloss aim to supply 
additional information to preserved original elements directly, the added information (e.g. words/phrases, parentheses and footnotes) can be seen as target-text oriented translation that aims to make readers more familiar with the source text as well.

Results

$5 \cdot 1$ The Identifications of Local and Global Translation Strategies

The study reveals that there are six adapted local translation strategies used in the translations of 984 venue and item markers. In order to identify a preferred global translation strategy, the occurrences of local translation strategies need to be determined based on the continuum between the two opposite poles. Here, analysis reveals the results shown in Figure 1 and Table 2.

Figure 1 and Table 2 show that 764 religious markers were translated using the literal translation strategy, which is classified as total exoticization. In addition, in-text and extra-text gloss, which show 15 and 83 occurrences respectively, incline towards the exoticizing pole. In sum, local translation strategies that incline towards the exoticizing pole total 862 . This accounts for $87.6 \%$ of the total number of 984 translated religious markers.

On the other hand, the remaining translated religious markers show a translation tendency towards the domesticating pole. Specifically, 114 religious markers which were translated using deletion and naturalization show total domestication, while 8 translated markers demonstrate a lesser degree of domestication as these markers were translated using the limited localization strategy. To conclude, these three local translation strategies constitute 122 occurrences in total, all of which incline towards the domesticating pole. These occurrences are $12.4 \%$ of the total translated religious markers.

Based on the statistics, local translation strategies that incline towards the exoticizing pole are dominant in the translation of Dan Brown's five translated novels. The exoticizing translations constitute $87.6 \%$ of the total translated religious markers, while those inclining towards the domesticating pole account for only $12.4 \%$. As a result, at this stage, it can be concluded that exoticizing translation is the global translation strategy predominantly adopted in the translation of Dan Brown's translated novels.

The dominance of exoticizing translation strategies give an important implication regarding readership in the Thai literary market. As discussed earlier, translation agents pay attention to the Thai readership, which is seen as specialized in terms of education level. The dominance of exoticizing translation strategies in the translations provides evidence that readership has been a consideration in the choice of translation strategies. More interestingly, the 
interview with the editor of Dan Brown's translations (Ratchatasuwan 2017) reveals that since readers are educated, they have not only the ability to complete the novels but sufficient interest to follow the translations from beginning to end. In addition, in their translation practices, the translation agents normally adhere to translation strategies that aim to retain foreign items in translations of culture-specific words/phrases, such as proper names, venue names, et cetera. On this basis, a link between the specialized readership and the dominant translation strategies is revealed.

The results of the study show that local translation strategies adopted in the translation of Dan Brown's five translated novels incline toward the exoticizing pole. There are higher frequencies of local translation strategies that manifest various degrees of exoticization than domestication. As illustrated above, these higher numbers of local translation strategies demonstrate that local translation strategies that appear on the exoticizing side are dominant in the translation.

In sum, the dominance of exoticizing translation strategies has a link with the specialized readership. Readers' level of education is seen as important in the translation process, where exoticizing translation strategies are adopted dominantly and are a manifestation of the resulting specificity. In this light, as the translation agents believe that their readers are educated, there is a basis to view that these readers "can be brought abroad" (through the translations of exoticizing strategies) to experience the foreign cultures.

Due to the study's limitations, a larger data corpus is needed in the future. It is likely that more data will lead to the discovery of a more evident preferred global translation strategy. In addition, a more extensive qualitative study to find out underlying elements that constitute a dominant global translation strategy is required. This will help to understand the relationship between adopted local translation strategies and local readers in the Thai context.

\section{References}

\section{Research Material}

Brown, Dan. 2000. Angels and Demons. 2009 edition, Reading: CPI Cox Wyman.

Brown, Dan. 2003. The Da Vinci Code. Second Anchor Books Mass-Market Edition, March 2009. New York: Anchor Books. 
Brown, Dan. 2004a. Thewa kap satan (Angels and Demons). $29^{\text {th }}$ Edition, March 2014. Translated by Oradee Suwankomol and Anurak Nakarin. Bangkok: Praew Publisher.

Brown, Dan. 2004b. Rahat lap dawinchi (The Da Vinci Code). $25^{\text {th }}$ Edition, April 2006. Translated by Oradee Suwankomol. Bangkok: Praew Publisher.

Brown, Dan. 2009. The Lost Symbol. First Anchor Books Open-Market Edition, July 2010. New York: Anchor.

Brown, Dan. 2010. San lap thi sapsun (The Lost Symbol). $16^{\text {th }}$ Edition, March 2014. Translated by Oradee Suwankomol. Bangkok: Praew Publisher.

Brown, Dan. 2014. Su narok phum (Inferno). Translated by Oradee Suwankomol. Bangkok: Praew Publisher.

Brown, Dan. 2016. Inferno. London: Corgi.

Brown, Dan. 2017. Origin. England: Corgi Books.

Brown, Dan. 2018. O ri cin (Origin). Translated by Anurak Nakarin. Bangkok: Praew Publisher.

Chiwasujin, Nichapa. 2016. Interview. Praew Printing and Publishing Public Company Limited. Bangkok, 11 August 2016.

Ratchatasuwan, Nakin. 2017. Interview. Praew Printing and Publishing Public Company Limited. Bangkok, 21 December 2017.

\section{Works Cited}

Aixelá, Javier Franco. 1996. “Culture-Specific Items in Translation.” In Translation, Power, Subversion, edited by Román Alvarez and M. Carmen Africa Vidal, $5^{2-78}$. Clevedon: Multilingual Matters.

Chesterman, Andrew. 2000 [1997]. Memes of Translation the Spread of Ideas in Translation Theory. Amsterdam: John Benjamins Publishing Company.

Chittiphalangsri, Phrae. 2014. "The Emerging Literariness: Translation, Dynamic Canonicity and the Problematic Verisimilitude in Early Thai Prose Fictions". In Translation and Global Asia: Relocating Cultural Production Network, edited by Uganda SzePui Kwan and Lawrence Wang-Chi Wong, 1-34. Hong Kong: The Chinese University of Hong Kong Press.

Davies, Eirlys. 2003. "A Goblin or a Dirty Nose? The Treatment of Culture-Specific References in Translations of the Harry Potter Book." The Translator 9 (1): 65-100.

Even-Zohar, Itamar. 1990. "Polysystem Studies." Poetics Today 11, No. 1 (Spring): https:// www.tau.ac.il/ itamarez/works/books/Even-Zohar_1990-PolysystemStudies\%20 $\%{ }_{5}$ BPT11-1\%5D.pdf.

Lefevere, Andre. 1992. Translation, Rewriting, and the Manipulation of Literary Fame. London; New York: Routledge.

Leppihalme, Ritva. 2001. "Translation Strategies for Realia." In Mission, Vision, Strategies, and Values: A Celebration of Translator Training and Translation Studies In 
Kouvola, edited by Pirjo Kukkonen and Ritva Hartama-Heinonen, 139-148. Helsinki: Helsinki University Press.

Liang, Wayne Wen-chun. 2016. "Translators' Behaviors from a Sociological Perspective A Parallel Corpus Study of Fantasy Fiction Translation in Taiwan." Babel 62 (1): 39-66.

Myskja, Kjetil. 2013. "Foreignisation and Resistance: Lawrence Venuti and his Critics." Nordic Journal of English Studies 12 (2): 1-23.

Paloposki, Outi. 2011. Domestication and Foreignization. In Handbook of Translation Studies Volume 2, edited by Yves Gambier and Luc Van Doorslaer, 40-42. Amsterdam: John Benjamins Publishing Company.

Robrue, Mett. 2007. A Study of the Translation of the Da Vinci Code by Dan Brown into Thai by Oradee Suwankomol. Master Thesis, Mahidol University.

Rutnin, Mattani Mojdara. 1988. Modern Thai Literature. Bangkok: Thammasat University Press.

Saldanha, Gabriela, and O'Brien, Sharon. 2014. Research Methodologies in Translation Studies. Oxon: Routledge.

Schleiermacher, Friedrich. 1977 [1838]. “On the Difference Methods of Translating.” In Translating Literature: The German Tradition from Luther to Rosenzweig, edited and translated by André Lefevere, 67-89. Assen: Van Gorcum.

Shamma, Tarek. 2009. Translation and the Manipulation of Difference: Arabic Literature in Nineteenth-Century England. Manchester: Routledge.

Venuti, Lawrence. 2008 [1995]. The Translator's Invisibility: A History of Translation. 2nd edition, Oxon: Routledge. 